\title{
Indigenizing Political Science or Decolonizing Political Scientists?
}

\author{
Franke Wilmer
} nsiders and outsiders both have important contributions to make to scholarly conversations so let me position myself: I am not an Indigenous person. When I decided to do dissertation research on international human rights in 1988, I settled on Indigenous peoples' rights because it appeared to be an issue completely marginalized by political science, particularly in the United States and certainly within the subfield of international relations. My methodology was not complicated: listen to Indigenous peoples tell their versions of how they came to be politically situated in the world today, put my perception of those stories into the context of contemporary discourses about international human rights, and share the resulting narrative and analysis with a broader audience of scholars, students, and activists. In my view, we must have meaningful conversations in which we are aware that we are different-Indigenous person, European settler person - and that we are the same-human beings-at the same time. It is in that spirit that I offer these thoughts about Kennan Ferguson's essay.

"Political science as a discipline," says Ferguson, has "erased Native identity, Native philosophy, and Native history from its areas of concern." Once again, political science is proven to serve the institutions it purports to theorize and study. American political institutions deliberately erased Indigenous identities, philosophies, and histories. The American project of nation building, animated by the ideology of "manifest destiny" had, at its core, the objective of completely and intentionally dispossessing Indigenous nations, who were here first, of their land, resources, and material basis for their cultural and spiritual existence. This objective was accomplished primarily through a protracted and sustained genocide of Indigenous peoples. Regardless of the extent to which accomplishing that objective was aided by the spread of epidemic diseases alien to the western hemisphere, the intentional violence, the ideology (including an American

Franke Wilmer is Professor of Political Science at Montana State University(franke@montana.edu). version of eugenics) that rationalized it, and the genocidal outcome, is for the most part invisible to most Americans. A "special edition" edited by National Geographic in the 1960s illustrates this point. Entitled Vanishing Peoples of the Earth, it is about Indigenous peoples. ${ }^{1}$ That's it. Poof. They were just "vanishing." Ferguson's use of the term "erased" seems understated.

While many of Ferguson's diagnoses of the problem warrant more and plurivocal discussion, there are two I find particularly germane to reconciling the exclusion of Indigenous peoples from political science. One is that the categories and concepts of the discipline transpose poorly onto Indigenous experiences and practices because they are a product of an academic enterprise that springs from the perspective of European colonial scholars. Two examples make this strikingly clear. One is from the Haudenosaunnee, Basic Call to Consciousness, Address to the Western World, where Indigenous speakers proclaim that "spiritual consciousness is the highest form of politics." 2 This assertion alone could generate a rich and extended theoretical dialogue between, and among Indigenous and European colonial philosophers. The second example is the attempt by Michael Lerma (P'urhépecha) to tackle what sovereignty means to Indigenous peoples and nations. Following Linda Tuhiwai Smith's directive to decolonize our methodologies (and ourselves), Lerma begins with an Indigenous conception of sovereignty as the "inherent responsibility many Indigenous peoples have to serve their traditional homelands." Indigenous scholar Dale Turner (2006) on the other hand, views Indigenous forms of political sovereignty as pluralistic, localized, and as yet largely unarticulated by Indigenous social scientists. ${ }^{4}$ Still, both approaches reject the notion that Indigenous peoples and nations should start with non-Indigenous meanings.

Secondly, I applaud Ferguson's indictment of the structure of institutional academia for excluding indigeneity from political science, but it is not for lack of trying to be included on the part of those who have made Indigenous issues and perspectives a central issue of their research. My dissertation became a book. It was assigned a call number by the Library of Congress. Its call number indicates that it is a book in the field of anthropology. 
Bingo. Colonized again. And that was my point. A point missed by whoever assigns those call numbers. Written by a political scientist, about the global political activism of Indigenous peoples, but if Indigenous is in the title, it must, apparently, remain academically colonized within anthropology.

"How can we indigenize political science?" Ferguson asks. Start with Linda Tuhiwai Smith's directive that we must first all decolonize ourselves. Just as patriarchy patriarchalizes, colonialism colonizes-all of us. We are socialized to view colonized norms as simply "norms" or "the norm." The ideological underpinnings are rendered invisible, so first we must make them visible before we can see how our own perceptions, thinking, and assumptions are colonized.

Ferguson identifies some of the most important North American Indigenous scholars working in political science (and misses some too), but he also seems to conflate Indigenous scholars with scholars whose work addresses Indigenous issues. In political theory, for example, three non-Indigenous scholars solicited chapters from a broad range of social and political theorists including four Indigenous scholars and published Political Theory and the Rights of Indigenous Peoples. ${ }^{5}$ It is odd that Ferguson seems unaware of this work since he is a theorist himself and could readily incorporate the book into his own pedagogy. True, only three of the seventeen are from the United States and most are non-Indigenous, and indeed this points to a more serious problem Ferguson highlights: political science practiced "outside" the United States has taken Indigenous politics more seriously than those on the U.S. mainland. This, I would argue, is mostly explained by the arrogance of (U.S. mainland) intellectual hegemony.

Finally, I want to address Ferguson's observation that there are so few Indigenous political scientists and my Indigenous colleagues and friends can correct me if I'm wrong. Indigenous communities faced with opportunities to channel Indigenous youth in to mainstream nonIndigenous professions have implicitly prioritized these choices in relation to their needs. With the goal of replacing non-Indigenous professionals whose work most directly impacts Indigenous communities with Indigenous professionals, they first, for obvious reasons, focused on training Indigenous lawyers; after that, $\mathrm{K}-12$ teachers; then social workers, counselors, and health care providers. Many college-bound Indigenous young people feel an implicit pressure to make choices about professional studies in terms of what will bring the greatest benefit to their communities. To put it differently, political science may "hate" Native Americans, but frankly, one reason there are not more Native American political scientists is that they have had other priorities ordered by the practical needs of their communities: combatting law court decisions that undermine their self-determination; taking control of their own public education; engaging Indigenous people and knowledge in providing much needed social services and community health. Understanding the current state of non-Indigenous political theory and practice is important to their survival and rebuilding self-determined post-genocide nations, although "indigenizing political science" may be less important. Still, I am glad Ferguson is bothered by the "erasure" of Indigenous scholars and scholarship and hope not only that this will lead him to incorporate them more into his own pedagogy and even his own scholarship, but also reinvigorate political scientists more broadly to do the same.

\section{Notes}

1 National Geographic in the 1960s illustrates this point. Entitled Vanishing Peoples of the Earth (National Geographic Society 1968).

2 Basic Call to Consciousness, Address to the Western World (Geneva, 1978).

3 Michael Lerma (P’urhépecha) (Lerma 2014:xiii); Linda Tuhiwai Smith's directive

4 Dale Turner (2006).

5 Political Theory and the Rights of Indigenous Peoples (Ivison, Patton, and Sanders, 2000).

\section{References}

Akwesasne, Notes. 1978. Basic Call to Consciousness: Address to the Western World. Geneva, Switzerland, and Mohawk Nation via Rooseveltown, NY.

Ferguson, Kennan. 2016. "Why Does Political Science Hate American Indians?" Perspectives on Politics 14(4): 1029-53.

Ivison, Duncan, Paul Patton, and Will Sanders. 2001. Political Theory and the Rights of Indigenous Peoples. Cambridge: Cambridge University Press.

Lerma, Michael. 2014. Indigenous Sovereignty in the $21^{\text {st }}$ Century: Knowledge for the Indigenous Spring.

Gainesville, FL: Florida Academic Press.

National Geographic Society. 1968. Vanishing Peoples of the Earth. Washington, DC: National Geographic Society.

Smith, Linda Tuhiwai. 1999. Decolonizing Methodologies: Research and Indigenous Peoples. London, UK: Zed Books.

Turner, Dale. 2006. This Is Not a Peace Pipe. Toronto, Ontario: University of Toronto Press.

Wilmer, Franke. 1993. The Indigenous Voice in World Politics. Thousand Oaks, CA: Sage Publications. 